\title{
脊髄虚血に対する Ca-Antagonist（Nifedipine）の効果
}

一静脈内投与による第一報一

\author{
山口労災病院
甲 斐之尋・大屋国 益
ワシントン大学
Jeffrey H. Owen
九州大学整形外科 \\ 杉 岡 洋 一
}

\begin{abstract}
Effects of Ca-Antagonist (Nifedipine) to Spinal Cord Ischemia
-Preliminary report of intravenous injection-
\end{abstract}

by

\author{
Yukihiro Kai and Kunimasu Ooya \\ Orthopaedic Surgery, Yamaguchi Rosai Hospital \\ Jaffrey H. Owen \\ Orthopaedic Surgery, Washington University \\ Yoichi Sugioka \\ Orthopaedic Surgery, Kyushu University
}

\begin{abstract}
It has been reported that the neuronal death induced by spinal cord ischemia would be mediated by a calcium influx through $\mathrm{Ca}$-channel. The aim of this experiment was to investigate the effect of Ca-antagonist (nifedipine) in spinal cord ischemia, indued by aortic crossclamping (AXC), using spinal evoked potential (spinal-EP) as an indicy. Firstly, we identified that infrarenal lumbar arteries would supply the blood-flow to lumbar part of spinal cord. On electrophysiological approach, we stimulated a pair of electrodes inserted into the disk of T12-13 and recorded from electrodes into the disk of L 5-6. The time to spinal-EP loss was measured as a group of control (Group C), after infrarenal AXC. As a group of Ca-antagonist (Group N), nifedipine $(30 \mu \mathrm{g} / \mathrm{kg}$ bolus followed by $10 \mu \mathrm{g} / \mathrm{kg} / \mathrm{min}$ ) was injected intravenously $30 \mathrm{~min}$ before AXC. The time to potential loss was checked under AXC-induced cord ischemia. Group N showed 3 min prolongation, compared with Group C.
\end{abstract}

\section{は じめに}

脊髄損傷の急性期においては, 直達のメカニカルな 外力による損傷に続いて，二次的に引き起こされる脊 髄虚血が問題となる．金髄虚血時における神経細胞死 のメカニズムとして，グルタミン酸を伝達物質とする 興奮性シナプス入力の増大によって生じた脱分極など による細胞内への $\mathrm{Ca}^{2+}$ の異常に立進した流入が関わ
りあっている ${ }^{2)}$. 最近, 種々の Ca-antagonist が菲 髄虚血や損傷に有効な治療手段となる可能性が諸家に より報告されるようになった ${ }^{3)}$ 4). 今回, 我々は神経 細胞死の原因となる細胞内 $\mathrm{Ca}^{2+}$ 異常上昇に直接関与 すると思われるCaチャネルの特徴に注目し ${ }^{1)}$, 家鬼 を用いて腰部脊髄の虚血を Aortic-crossclamping (AXC) により作成, Spinal evoked potential (Spinal-EP) を指標として, Ca-antagonist (Nife- 


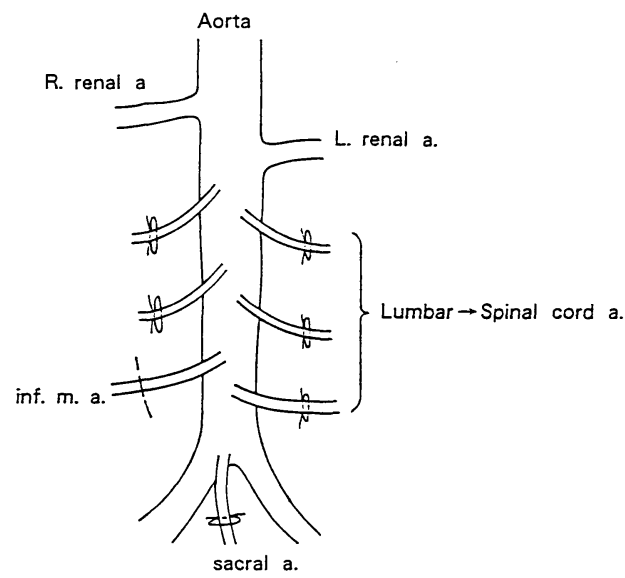

A

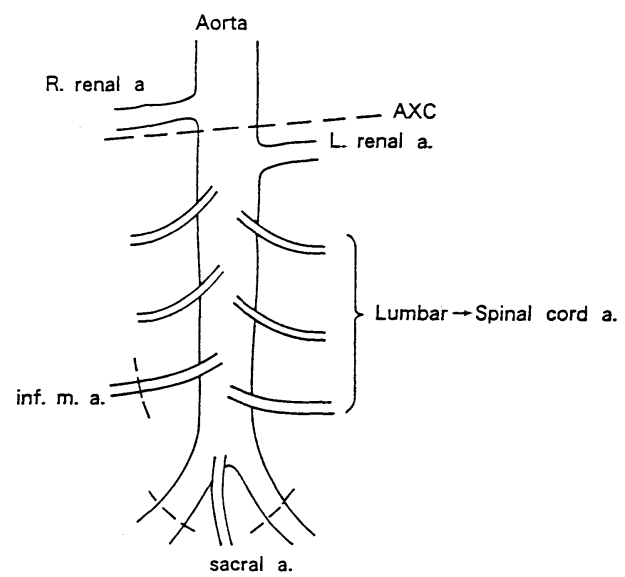

B

図 1 A. 腰動脈の結禁 B. infrarenal AXC

dipine）の効果を調べた.

方法

家鬼を 0.5-1.5\%ハロセン麻酔下に開腹, Aorta を 露出した，腰部脊髄への血液供給動脈を同定するため, 腰動脈を剥離, 図 1-A の如く結紮し, 電気生理的ア プローチ及びWake-up testを用いて評価した。電 気生理的には， $\mathrm{T}_{12-13}$ 及び $\mathrm{L}_{5-6}$ の椎間板へ電極を刺 入し, $\mathrm{T}_{12-13}$ を刺激, $\mathrm{L}_{5-6}$ で記録される Spinal-EP を指標とし, infrarenal 腰動脈結紫後の電位消失を チェックした．刺激は頻度 $4.8 / \mathrm{sec}, 0.1-0.2 \mathrm{msec}$ 巾の矩形波, 強度 20-40 mA を用いた。周波教帯域 は $10 \mathrm{~Hz}-1.5 \mathrm{k} \mathrm{HZ}$, 分析時間 $15 \mathrm{msec}$, 加算 100 回 で記録（Nicolet-Compact four）した. wake-up test は実験終了直後及び 24 時間後に評価された.

次に，コントロール群として図 1 -B 破線の如く $\mathrm{AXC}$ を施行し, AXC 後の spinal-EP 消失までの時 間及び解放後の電位回後までの時間を測定した.

Ca-antagonist（Nifedipine）投与群は，30 $\mathrm{g} /$ $\mathrm{kg}$ bolus 後, 毎分 $10 \mu \mathrm{g} / \mathrm{kg}$ で持続静注し, 30 分間 の血圧, spinal-EP, 心拍数, CVP をチェックし, 同様に AXC 後の spinal-EP の消失, 回復時間を比 較測定した。
Spinal- EP ( LS )

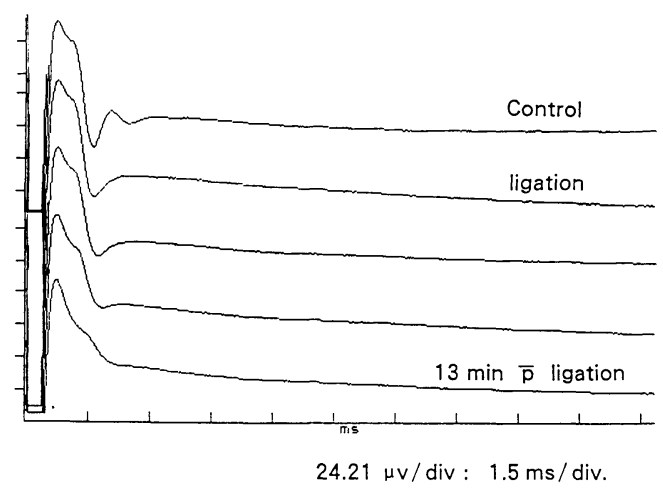

図2 腰動脈結紮後. 13分でSpinal-EP 消失

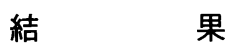

\section{1 ）腰部脊髄への血液供給}

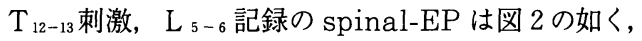
infrarenal 腰動脈結禁後平均 $13.4 \pm 2.92$ 分 (Mean 土SD）にて消失した. 実験終了直後のwake-up test は全例（ $\mathrm{N}=6 ）$ で完全麻疩を呈し，24 時間後に評 価し得た 3 例全例も麻瘏であった。

2) Nifedipineの効果 
A

Spinal-EP( LS )

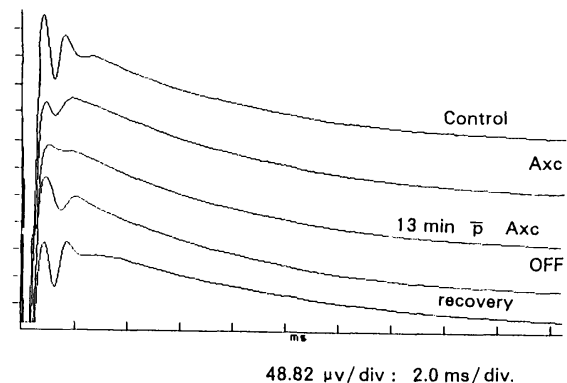

B

Spinal- EP ( LS )

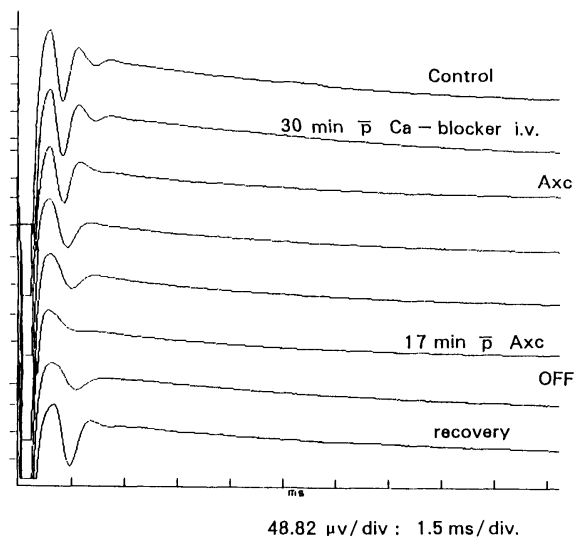

図3A; AXC 後. Spinal-EPは13 分で消失 B ; nifedipine 投与後 30 分. Spinal-EP 不変. AXC 後 17 分で消失した.

前述 1 ）の結果に従い, infrarenal AXC を施行 し, Spinal-EP は平均 $13.3 \pm 2.67$ 分で消失した（コ ントーロル群). 解放後, 約 $3.0 \pm 1.2$ 分で電位は回復 した（図 3-A). Nifedipine 投与群では静注後, 血 圧（正常 90-120 mmHg）は平均 $10 \mathrm{mmHg}$ 低下し たがSpinal-EP（図 3-B）は変化せず，心拍数， CVP も変化しなかった. $\mathrm{AXC}$ 後, 図 3 - B の如く 電位消失, 平均 $16.3 \pm 4.38$ 分で消失, 解放後は $4.5 \pm$ 2.1 分で回復した。

\section{考察}

神経損傷あるいは虚血時における Nifedipine の効 果は過去に報告され, Hall らは nifedipine は脊髄血 流を増加させ虚血時の血流低下を防止したと報告し ${ }^{6)}$, in vitroでも Weiss らは損傷時に細胞内への Cainflux が重要な鍵となり, Nifedipineがそれを減少 させたと報告した ${ }^{9)}$. Ca-channel antagonist は神 経損傷時に打いて，神経血流増加や血管拡張， Cainflux の防止などの作用により防御手段となり得る 可能性をもっていると言える ${ }^{3 / 4) 5 / 6)}$. 今回の実験系 では, 投与量, 投与方法, 評価方法, 薬䯇の種類 ${ }^{6) 81}$ など検討は不充分であったが，期待したほどの SpinalEP の消失時間の延長は認められなかった. Nifedipine による薬理効果を考えるとき，血圧低下による脊䯣血 流の低下の可能性も考えられる ${ }^{4)}$ 5). 血圧維持户 AXC の CSF 圧上昇に対しての効果 ${ }^{7)}$ など検討されるべき 複雑な要因は多く，in vivo の実験系では，これらを 加味して検討すべきであった，今回の電気生理的評価 により, Nifedipine 投与群の電位消失はコントロー ル群に比して約 3 分延長した. Nifedipine 以外の Ca-antagonist の脊髄虚血に対する効果が真に有効 であるかどうかは今後の検討を待たねばならない．今 回, in vivo 電気生理的評価による第一報を報告した。

\section{参 考 文 献}

1）赤池紀扶：哺乳動物中枢神経細胞のパッチクランプ. 実験医学 7, No. $6:$ 130-135, 1989.

2) Choi, D. W.: Glufamate neurotoxicity in cortical cell culture is calcium dependent. Neurosci. Lett. 58 : 293-297, 1985

3) Faden, A. I. et al.: Evaluation of the calcium channel antagonist nimodipine in experimental spinal cord: ischemia. J Neurosurg. 60 : 796-799, 1984.

4) Gelbfish, J.S. et al.: Acute spinal cord ischemia: prevention of paraplegia with verapamil. Circulation 74 (Suppl I) : 5-10, 1986.

5) Guha, A. et al.: Effect of calcium channel blocker on posttraumatic spinal cord blood flow. J Neurosurg $66: 423-430,1987$.

6) Hall, E. D. et al.: A pharmacological analysis of the pathophysiological mechanisms of posttraumatic spinal cord ischemia. J Neurosurg. 64 : 951-961, 1986.

7) Hollier, V.H. et al.: Protecting the brain and spinal cord. J. Vascular surg. 5. No. 3 : 524-528, 1987.

8) Martinez-Arizala, A. et al.: Effect of NMDA Receptor Antagonist following spinal ischemia in the rabbit. Exp. Nenrology 108 : 232-240, 1990.

9) Weiss, J.H. et al.: the Calciuum channel blocker nifedipine Attenuates slow. excitatory amino acid neurotoxicity. Science $247: 1474-1477,1990$. 